\title{
Arbel mediko baten erabileraren azterketa: nolako elkarrekintza halako portaera-bisuala
}

\author{
(Analisys of the use of a medical dashboard: interaction reveals \\ visual behaviour)
}

\author{
Ainhoa Yera*1, Olatz Arbelaitz ${ }^{1}$, Javier Muguerza ${ }^{1}$, Iñigo Perona ${ }^{1}$, Markel Vigo ${ }^{2}$ \\ ${ }^{1}$ Euskal Herriko Unibertsitatea - UPV/EHU, Donostia, Euskal Herria \\ ${ }^{2}$ University of Manchester, United Kingdom
}

\begin{abstract}
LABURPENA: Osasun-arlorako softwarean, beste esparru askotan bezala, erabilgarritasuna erronka handia da; batetik, datuak ugariak eta konplexuak direlako eta, bestetik, erabilera-testuingurua kritikoa delako. Jakina da langile klinikoek informazio kopuru egokia eskatzen dutela beren zereginak aurrera eramateko, eta, zentzu horretan, erabiltzaile-interfaze moldagarriak oso baliagarriak izan daitezke informazio-behar horiek asetzeko nahiz informaziogainkargaren arazoari heltzeko. Erabiltzaile-interfazerako egokitzapenak inplementatu aurretik, baina, aldakorrak diren informazio-behar horiek identifikatu eta lehenetsi egin behar dira. Begi-arakatzaileak lagungarriak izan daitezke zeregin hauek erdiesteko, erabiltzaileen portaera bisuala antzeman baitezakete, zeina interesaren adierazle den. Zoritxarrez, arakatzaile horiek sistema hedatu batean erabiltzeak azpiegitura konplexuegia eskatzen du. Ekarpen honetan aztertu dugu ea erabiltzaileen portaera bisuala inferi ote daitekeen erabiltzaile horiek botiken segurtasunari lotutako arbel batean izandako elkarrekintzaren datuetatik abiatuz. Emaitzek aditzera eman dute bi alderdiak, hots, saguaren bidezko elkarrekintza eta portaera bisuala (karga kognitiboa), lotuta daudela; ezaugarri hauen arabera neurtuak, hurrenez hurren: saguaren ondoz ondoko bi kliken arteko denbora-tarteak eta sagu-pausatzeak, batetik, eta, bestetik, begiradaren finkapenaren iraupenak. Lanak eztabaidatzen du zer eragin izan dezakeen aurkikuntza horrek arbel medikoen egokitzapenen diseinuan.
\end{abstract}

HITZ GAKOAK: arbel medikoa, portaeraren modelatzea, elkarrekintza, begirada.

\begin{abstract}
Usability is a big challenge for medical software, on one side because data are of large size and complex and on the other because the context of use is critical. We know that clinicians call for the right amount and to this regard, adaptive user interfaces can help not only identifying these information needs but also alleviating the data overload. However, before implementing user interface adaptations, these particular information demands have to be identified and prioritised. Eye-trackers can help accomplishing such tasks, since they can gather the visual behaviour of users, which depict interest, but using them in a deployed system requires a complex infraestructure. In this contribution, we analyse whether visual behaviour of users on a medication safety dashboard can be inferred from their interaction data. The results show that the use of the mouse interaction and visual behaviour (cognitive load) are some-how connected, measured in terms of the following features respectively: dwell time and mouse hovers between two consecutive clicks, and duration of gaze fixations. The article discusses the significance of this statement for the design of adaptations in medical dashboards.
\end{abstract}

KEYWORDS: Medical dashboard, behaviour modeling, interaction, gaze.

* Harremanetan jartzeko / Corresponding author: Ainhoa Yera. Euskal Herriko Unibertsitatea (UPV/EHU), Manuel Lardizabal Ibilbidea, 1 (20018 Donostia, Euskal Herria). - ainhoa.yera@ehu.eus - https://orcid.org/0000-0002-5800-6654.

Nola aipatu / How to cite: Yera, Ainhoa; Arbelaitz, Olatz; Muguerza, Javier; Perona, Iñigo; Vigo, Markel (2020). "Arbel mediko baten erabileraren azterketa: nolako elkarrekintza halako portaera-bisuala»; Ekaia, 38, 2020, 295-314. (https://doi.org/10.1387/ekaia.21695).

Jasoa: 02 maiatza , 2020; Onartua: 01 uztaila , 2020.

ISSN 0214-9001 - eISSN 2444-3255 / (C) 2020 UPV/EHU 
Ainhoa Yera, Olatz Arbelaitz, Javier Muguerza, Iñigo Perona, Markel Vigo

\section{SARRERA}

Osasun-arloko profesionalen erantzukizuna (familia-medikuena, bereziki), orain arte, paziente bakoitzaren aurrean erreakzionatzera mugatzen zen; egun, ordea, erantzukizun hori aldatzen ari da, eta populazioaren osasunaren administratzaile izatea da. Eraldaketa hori gauzatzeko, beharrezkoak dira bai osasun-datuak eta bai datu horien populazio-mailako ikuspegia eskaintzen duten informazio-tresnak, zeinek esku-hartzea behar duten paziente indibidualak identifikatzea ahalbidetzen baitute. Ondorioz, arbel medikoen erabilera gero eta garrantzitsuagoa bilakatzen ari da, baina arbel askok informazio-gainkarga izaten dute, eta horrek arazoak sortzen ditu. Gainera, medikuek esperientzia klinikoaren eta praktikoaren maila desberdinak dituzte; arazoak konpontzeko gaitasunak oso askotarikoak dituzte, eta desberdinak dituzte, halaber, informazioaren teknologietako gaitasunak. Testuinguru honetan, beraz, berebiziko garrantzia du egokitze-gaitasuna duten sistema adimendunak eraikitzeak; sistema horiek medikuen beharrak aseko dituzte, eta biztanleriaren osasunaren kudeaketa proaktibo baterako trantsizioan lagunduko dute.

Arbel medikoek biztanleriari buruzko datuak erakusten dituzte, eta komunitateen osasuna kontrolatzeko eta medikuei erabakiak hartzeko jardueretan laguntzeko erabiltzen dira [10]. Lan batzuek arbelen izaera bisualaren onurak nabarmentzen dituzte: esaterako, diabetesa zaintzeko esku-hartze arrakastatsuak [8] eta elkarrekintza farmakologikoek eragindako alerten kudeaketa [23]. Normalean, arbel medikoek datuak taula moduan erakusten dituzte, eta erabiltzaileen pertzepzioak eta ezagutzak (kognizioak) gainkarga ditzaketen elementuak izan ohi dituzte: irudiak, grafikoak, zenbakizko eta testuzko informazioa kasu. Arbelek informazio-gainkarga arintzen lagun badezakete ere, paradoxikoki, arbelek eruek ere sor dezakete arazo hori, informazioz eta trepetez (widgetez) jositako pantailak erakutsiz; fenomeno hori «arbel-olde» izenez ere ezagutzen da [16].

Informazio-gainkarga eta erabilgarritasun-maila eskasa arazo ezagunak dira historia kliniko elektronikoen sistemetan (HKE) [20, 22]. Arazo horri aurre egiteko, ingurune kliniko zehatzekiko eta dagozkien ohiko zereginekiko sentikorrak diren erabilgarritasun-arauak sortu ohi dira helburu orokorreko arauetatik $[18,29,5]$. Nolanahi ere, erabilgarritasun-arauen inplementazioak erabilgarritasun-arazo nabarmenenei eta kritikoenei aurre egin diezaiekeen arren, pantailako informazioa gehiegizkoa izan daiteke erabiltzaileentzat.

Horren aurrean, erabiltzaile-interfazeetarako ezaugarri pertsonalizatuak eta moldagarriak inplementatzea iradoki dute zenbait autorek helburu desberdinekin: ikuskaritza eta feedback esku-hartzeen konplexutasuna arintzea [19], informazio-gainkarga gutxitzea historia kliniko elektronikoetan [28], eta erabakiak hartzeko tresna klinikoen eraginkortasuna ho- 
betzea [4]. Arbel medikoen kasuan, horrelako ezaugarriak inplementatzea ez da lan erraza; izan ere, erabiltzaile-interfazea erabiltzailearen beharretara egokitzeko behar horiek erauzteaz gain, eskatu egiten du erabiltzailearen trebetasunak eta esperientzia ere kontuan hartzea [9], eta hori lan zaila da, erabiltzaileak denbora igaro ahala joango baitira ezagutza hobetuz. Ondorioz, erabiltzaileen trebetasunera eta esperientziara egokitzen diren sistemek automatikoki eta diskretuki arakatu beharko dituzte gaitasunak.

Testuinguru honetan, ikerketa-galdera honi erantzun diogu: Arbel medikoen erabiltzaileek ordenagailuarekin izandako elkarrekintza oinarri hartuta, posible al da erabiltzaile horien portaera bisuala ondorioztatzea? Badaude ikerketak erabiltzaileen begirada interesaren adierazle ona dela [11] diotenak, eta elkarrekintzen arteko erlazioa aztertzen dutenak, sagua eta begirada oso erlazionatuta daudela ondorioztatuz: begirada zonalde espezifikoetan egon den denbora-tarteak zonalde hori saguarekin bisitatzeko probabilitatearekin korrelazioan daude [6]. Bilatzaileen emaitzen orrietan (Search Engine Result Pages, SERP) begirada non pausatuko den iragartzeko ereduetan $\% 77 \mathrm{ko}$ asmatze-tasa lortu izan da, saguaren koordenatuak, abiadura eta norabidea, eta emaitzak bistaratzen direnetik igarotako denbora erabilita [13]. Hala ere, webguneek eta SERPek ez bezala, arbel medikoek taula-diseinua izan ohi dute, eta horrek erakuts daitezkeen portaeren aniztasuna baldintzatzen du.

Lan honetan aurkezten den analisia Salford Botiken Segurtasun Arbelean egin zen (Salford Medication Safety Dashboard [SMASH]); zehazki, farmazialariei zuzendutako informazio-sistema batean, lehen mailako arretan sendagaiak modu seguruan preskriba ditzaten sortua. 2. atalean, SMASH esku-hartzearen helburua eta funtzionalitateak azalduko ditugu eta 3.ean, berriz, egindako erabiltzaile-azterketak. Jarraian, 4. eta 5. ataletan, azterketa egiteko erauzitako ezaugarriak eta datu-baseak deskribatuko dira. Lortutako emaitzak 6. atalean laburbiltzen dira, eta 7.ean, aldiz, ondorio eta etorkizunerako lanak.

\section{TESTUINGURUA: SMASH ESKU-HARTZEA}

SMASH esku-hartzearen helburua da zehaztea ea farmazialariei zuzendutako esku-hartze konplexu bat aurrera eramateak murrizten ote duen arriskutsuak izan daitezkeen botiken preskripzio- eta kontrol-praktiken eragina, Salford hiriko lehen mailako arretan. Salford Erresuma Batuan, Manchester Handiaren zabalgunean dagoen 270.000 biztanleko hiria da [27]. SMASH arbela 2016an inplementatu zen, eta arriskutsuak izan daitezkeen preskripzio-tasen eraginaren ebaluazio kuantitatiboa abian da, eta prozesu kualitatiboaren aldibereko ebaluazioa argitaratua dago dagoeneko [15]. 
Ainhoa Yera, Olatz Arbelaitz, Javier Muguerza, Iñigo Perona, Markel Vigo

SMASH esku-hartzeak bi osagai nagusi ditu. Lehena, webean oinarritutako arbel interaktibo bat da, praktika orokorretan arriskutsuak izan daitezkeen preskripzioen eraginpean dauden pazienteei buruz ohartarazten duena. Bigarren osagaia farmazialariei zuzendutako laguntza klinikoa da; medikuen lankidetzaz baliatzen da, eta preskripzio-kasu arriskutsuak ebatzi, eta etorkizunean berriro gertatzea eragozten du, erro-kausa analisiaren bidez. SMASH esku-hartzea informazioaren mugarri izandako beste esku-hartze baten jarraipena da; farmazialariek zuzendutako eta teknologian oinarritutako entseguarena (Pharmacist-led information technology intervention for medication errors, PINCER), hain zuzen [3], baina arbel interaktiboaren erabilera berria da.

SMASH arbela interes-taldeko kideekin batera diseinatu zen [17], eta egindako preskripzioaren segurtasunari buruzko 13 adierazle erabiltzen ditu. Adierazle horiek, aldez aurretik, arriskutsuak izan daitezkeen sendagaien preskripzio-tasak neurtzeko eta monitorizatzeko erabili izan dira $[1,24]$. Esate baterako, arbelak ultzera peptikoaren aurrekariak dituzten paziente guztiak identifikatzen ditu, zeinei botika antiinflamatorio ezesteroide bat errezetatu baitzaie (adibidez, ibuprofenoa) sendagai urdail-babeslerik preskribitu gabe. Horrek pazienteak urdail-hesteetako odoljarioa izateko arriskuan jartzen ditu; heriotza-tasa altuak dituen gertaera kaltegarri garrantzitsua, hain zuzen ere. Arbelak laburpen estatistikoa erakusten du adierazle bakoitzerako: praktika jakin batean une horretan arriskuan dauden pazienteak zenbatzen ditu, eta zenbaki horiek aurreko gertakariekin eta beste praktika batzuekin erlazionatzen ditu. Horretaz gain, langile klinikoek une horretan adierazle bakoitzerako arriskuan dauden pazienteak ikus ditzakete.

1. irudian erakusten den bezala, SMASHen erabiltzaile-interfazea zazpi pantaila edo ikuspegitan banatzen da. (a) $P 1$ : hasierako orria da, praktika jakin baten laburpen-taula du, zeinak praktikaren tamaina eta adierazle batek baino gehiagok eragindako pazienteen kopurua baititu barnean. (b) $P 2$ : taula bat da, eta adierazleek eragindako pazienteen kopurua, pazienteen larritasun-maila, paziente hautagarrien kopurua eta eragindako pazienteen ehunekoa erakusten ditu; adierazleak botiken eta baldintzen arteko kontraindikazioak izan daitezke: adibidez, hanturaren kontrako botika ez-esteroideak (HKEE) eta giltzurrunetako gaixotasun kronikoa, edo botiken, ohituren eta datu demografikoen artekoak. (c) P3: adierazleek duten eragina denborazko serie gisa erakusten duten grafikoak dira. $P 2$ taula-ikuspegian arriskuan dauden pazienteen kopurua sakatzean, (d) $P 4$ pantailara sartzen gara; adierazle jakin baterako arriskuan dauden pazienteen zerrenda erakusten du. (a) $P 1$ laburpen-orrian dagoen «adierazle batek baino gehiagok eragindako pazienteak» estekan klik egitean, aldiz, (d) $P 5$ pantailara iristen gara; $P 4$ ikuspegiaren antzekoa da, baina adierazle bat baino gehiagoren eragina jasotzen duten pazienteak bakarrik erakusten ditu. $P 6$ pantailak 
adierazle jakin batek denboran zehar izan dituen joerak erakusten ditu, eta (f) $P 7$ ikuspegiak, aldiz, adierazle jakin bat arriskutsutzat zergatik jotzen den argitzen duen literatura medikoari buruzko informazioa eta pistak biltzen ditu.

SMASH arbela webean oinarritua izanik, web-nabigatzaile bat duen edozein gailu elektronikotan (ordenagailua, tableta e.a.) funtzionatzen du, erabiltzen diren sistema-eragilea eta elkarrekintza-gailua (sagua, hatza e.a) edozein direla ere. SMASH arbelak erabiltzaileen elkarrekintzaren ondorio diren erabiltzaile-interfazeko gertaerak erregistratzen ditu, zerbitzariko datu-base batean. SMASH saguz kontrolatutako aplikazioa denez, bildutako gertaera gehienak sagu-pausatzeak (mouse hovers) eta klikak dira. Orrialdea kargatzeko gertaera ere erregistratzen da, erabiltzailea pantaila batetik bestera nabigatzen ari dela adierazten duena (adib., $P 2$ taula-pantailatik $P 3$ bistaratze-pantailara). Gertaera 'Hautaketa-menuan' klik eginez aktibatzen da, eta ez du zertan URLaren eguneraketa ekarri. Gertaera bakoitzerako, SMASHek honako ezaugarriak gordetzen ditu: erabiltzailearen eta saioaren identifikatzaileak, denbora-marka eta gertaeraren kokalekua, hau da, dagozkion URLa eta erabiltzaile-interfazeko elementu espezifikoa (XPATH motako adierazpen batek zehaztua).

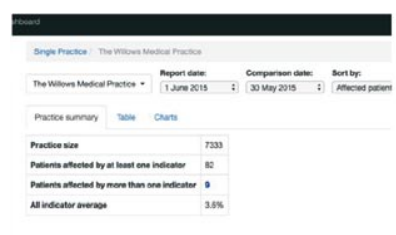

(a) $P$ 1: pantaila orokorra

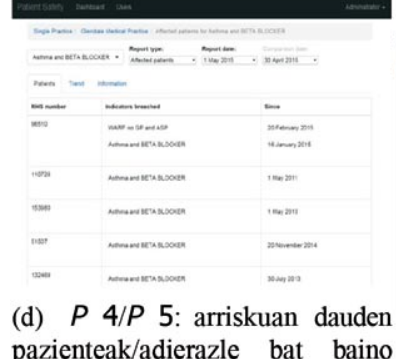
pazienteak/adierazle bat baino gehiagoren eragina dutenak

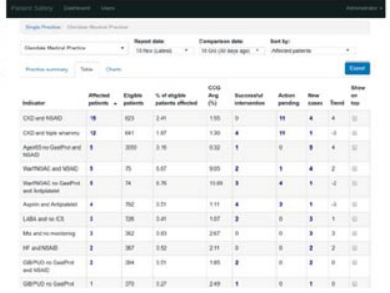

(b) P2: taula-ikuspegia

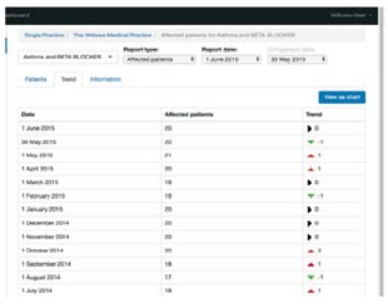

(e) $P 6$ : joerak

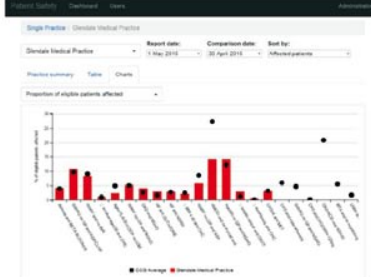

(c) P3: bistaratzeak

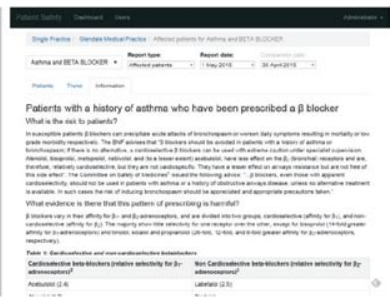

(f) P7: adierazlearen informazioa

1. irudia. SMASH arbelaren pantailak: (a) $P 1$ : praktikaren laburpena, (b) $P 2$ : segurtasun-adierazleen taula-ikuspegia; (c) $P 3$ : segurtasun-adierazleen bistaratzea; (d) P4/P5: arriskuan dauden pazienteen zerrenda; (e) $P 6$ : adierazleen joerak eta (f) $P 7$ : segurtasun-adierazle bat arriskutsutzat jotzeko dauden frogak erakusten dituen pantaila. 
Ainhoa Yera, Olatz Arbelaitz, Javier Muguerza, Iñigo Perona, Markel Vigo

\section{ERABILTZAILE-AZTERKETAK}

Gure analisian, lehenik eta behin, SMASH arbel medikoarekin egindako laborategiko azterketako parte-hartzaileen begirada-datuak eta elkarrekintzadatuak aztertu genituen: begi-arakatzaile batek eta arbelak berak bildutakoak, hurrenez hurren. Aurretik egindako azterketa pilotu bateko begirada-patroiak oinarri hartuta, interes-eremu (IE) batzuk zehaztu ziren, laborategiko azterketako begirada-datuak erregistratzeko aintzat hartu zirenak. Bigarrenik, behaketa-azterketa batean zehar jasotako parte-hartzaileen elkarrekintza-datuak ere aztertu genituen. Jarraian, hiru azterketak azalduko ditugu.

\subsection{Azterketa pilotua}

Azterketa pilotuan, batez beste 39 urte zituzten (desbideratze estandarra $=13,5$ eta adin-tartea $=27-62$ ) bost erabiltzailek (hiru emakume) parte hartu zuten. Guztiek tresna informatikoak erabiltzeko ohitura handia zuten, eta botiken segurtasun-arbelen domeinua eta terminologia ezagutzen zuten. Bi parte-hartzaile osasun elektronikoaren inguruko azterketetan maiz parte hartzen duen erabiltzaile-taldeko kideak ziren (Research User Group); beste batek erizaintzako gradu bat zuen; laugarren bat erizaintzako doktoretza egiten ari zen, eta azkena mikrobiologo medikoa zen.

Azterketa honetan, Tobii X2-60 [25] begi-arakatzailea erabili zen begiradaren informazioa erregistratzeko. Gailu honek begirada-datuak $60 \mathrm{~Hz}-$ eko maiztasunarekin erregistratzen ditu, eta, gehienez ere, 25 hazbeteko pantaila (16:9 alderdi-ratioa) erabiltzea gomendatzen du; honako informazioa jasotzen du: denbora-marka $(\mu \mathrm{s})$; ezkerreko/eskuineko begiradaren puntua: X, Y (koordenatu horizontala, X, eta bertikala, Y, dagokion begirako); begi bakoitzaren posizioa: X, Y, Z (begi bakoitzaren 3D posizioa begi-arakatzailearekiko); begi-nini bakoitzaren diametroa, eta ezkerreko/eskuineko baliozkotze-kodea (begi-arakatzaileak begi bakoitza behar bezala identifikatzeko duen konfiantza-maila adierazten du kode horrek).

Azterketa honetako parte-hartzaileei hiru multzotan sailkatutako bederatzi ataza osatzeko eskatu zitzaien: a) arriskuan dauden pazienteen identifikazioa: adib., «Zerrendatu $X$ adierazlerako arriskuan dauden hiru paziente»; b) praktikan izandako arazoen identifikazioa eta denboran zehar izan duten bilakaera: adib., «Identifikatu paziente kaltetu kopuru handiena duten hiru adierazleak»; c) praktiken arteko arazoen konparazioa: adib., «Identifikatu hiru adierazle, zeinetan zure praktikak besteek baino okerrago funtzionatzen duen».

Azterketa pilotuan bero-mapen analisi kualitatibo batetik ondorioztatu zen arbelean egindako bilaketa bisualek patroi zehatzei jarraitzen zietela. 2. irudiak SMASHen pantaila desberdinetan sortutako bero-mapen patroien adibide batzuk erakusten ditu. 


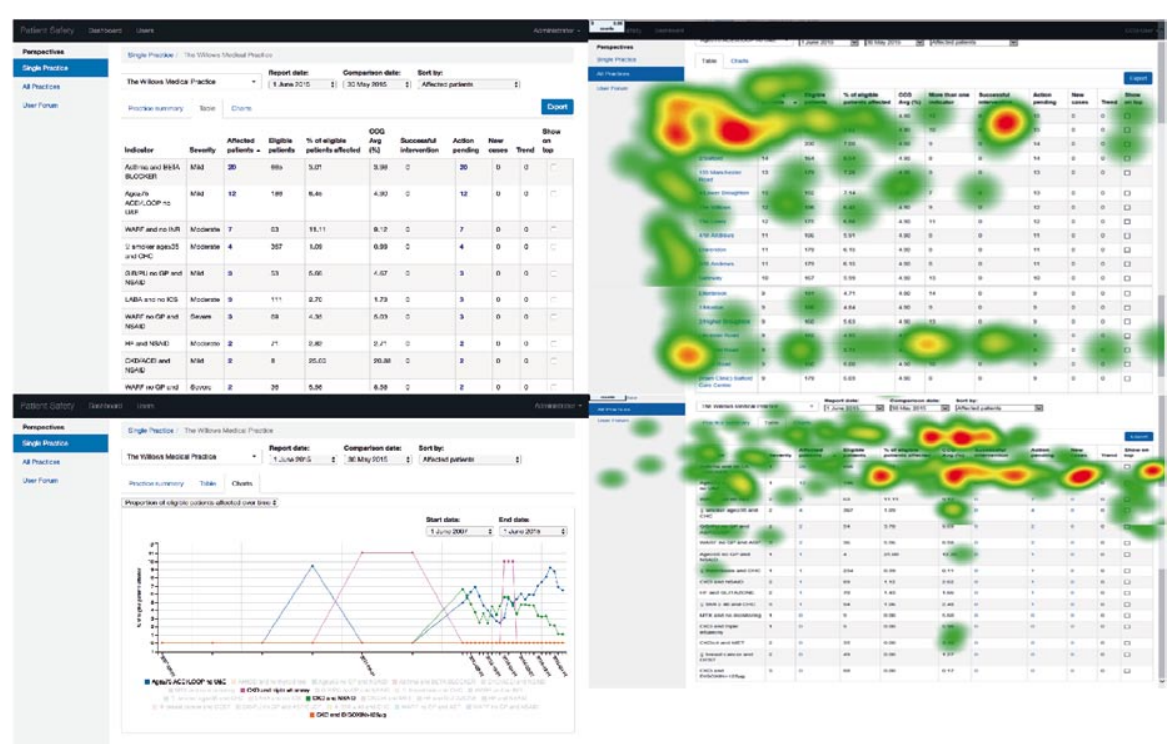

2. irudia. Azterketa pilotuan sortutako bero-mapen patroiak (eskuinean) SMASHeko taula-ikuspegian (goian, ezkerrean) eta bistaratze-pantailan (behean, ezkerrean).

2. irudian (goian, eskuinean) antzematen zaion C-formako portaerak iradokitzen du erabiltzaileek honako elementuei erreparatzen dietela: datuen goiburua, ezkerreko adierazleen zerrenda eta adierazle jakin bati dagozkion balioak. Bestalde, 2. irudian (behean, eskuinean) margo tanten gisako patroiak adierazten du erabiltzaileek goiburuko eta goiko parteko ilarei erreparatzen dietela eta bilaketa bisuala zutabe gutxi batzuetara mugatuta dagoela. Horren azalpena izan liteke erabiltzaile batzuk ohartu direla ezen, goiburu batean klik egitean, dagokion zutabearen/aldagaiaren balioen arabera antolatzen direla adierazleak, eta beraz, ataza asko modu eraginkorrean osa ditzaketela esplorazio bisualen kopurua murriztuta. Arbeleko elementuen arteko mugak argiak badira ere, zaila da taula moduko ingurune batean interes-eremuak definitzea.

Hautemandako begirada-patroiak eta erabiltzaile-interfazean dauden elementuen mugak oinarri hartuta, bederatzi interes-eremu diseinatu ziren: (IE1) fitxategi menua, (IE2) hautaketa menua, (IE3) ezkerreko menua, (IE4) praktikaren laburpena, (IE5) datuen goiburua, (IE6) adierazleak, (IE7) datuen taula, (IE8) grafikoa (datu-bistaratzea) eta (IE9) menu zabalgarria (klik egin ostean zabaltzen den edozein menu zabalgarri). 3. irudian ikus daitekeenez, emaitzek iradokitzen dute segurtasun-adierazleak erakusten dituen zutabeak, taularen goiburuak eta gainerako ilarek osatu beharko lituzketela interes-eremu independenteak. 
Ainhoa Yera, Olatz Arbelaitz, Javier Muguerza, Iñigo Perona, Markel Vigo

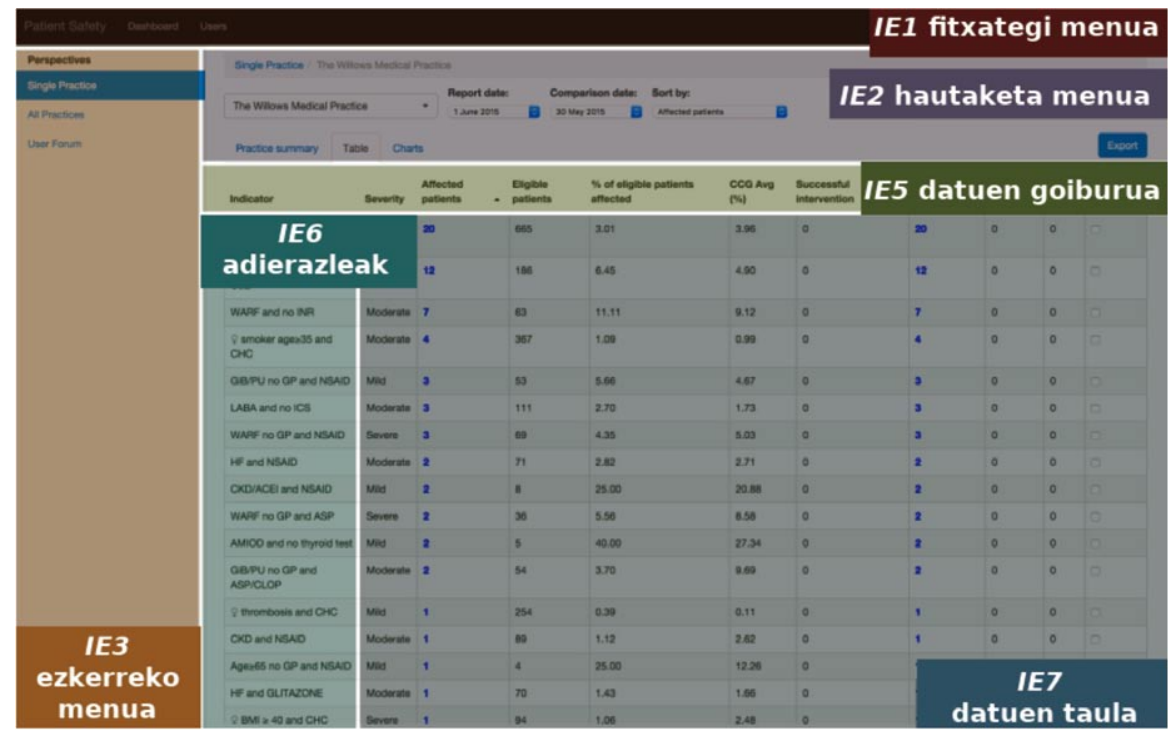

3. irudia. SMASH arbelean definitutako sei interes-eremu (IE1-IE3 eta IE5IE7), bederatzi posibleetatik; gainerako hiru IEak laster-leihoei (IE4 eta IE9) eta grafikoei (IE8) dagozkie.

\subsection{Laborategiko azterketa}

Laborategiko azterketan sei erabiltzailek (lau gizon) parte hartu zuten: bost familia-mediku eta farmazialari bat; haien batez besteko adina 38 urte zen (desbideratze estandarra $=10$ eta adin-tartea $=30-56$ ). Azterketa honetan, azterketa pilotuko Tobii X2-60 begi-arakatzailea [25] erabili zen begiradaren informazioa erregistratzeko: zehazki, finkapen-koordenatuak pantailan, eta bi finkapenen arteko begien mugimenduen iraupenak. Aipatu moduan, begirada-datuak SMASHen interfazearen bederatzi interes-eremu nagusien arabera erregistratu ziren (ikus 3. irudia). Kasu honetan ere, partehartzaileei azterketa pilotuan deskribatu berri diren bederatzi atazak betetzeko eskatu zitzaien. Azterketa honek Manchesterreko Unibertsitateko eta bertako Informatika Fakultateko Ikerketaren Etika Batzordearen onespen etikoa jaso zuen (CS 152b erreferentzia-zenbakia).

\subsection{Behaketa-azterketa}

Behaketa-azterketak 10 hilabetez iraun zuen, eta tarte horretan 35 erabiltzailek (10 farmazialari eta 25 ez-farmazialari) SMASH arbelarekin izandako elkarrekintzaren datuak bildu ziren. 
Ez-farmazialarien taldean, Batzorde Klinikoko (Clinical Commisioning Group) zortzi kide, zortzi familia-mediku eta bost kudeatzaile zeuden, eta bestelako lau parte-hartzaile, erizainak eta farmazia-teknikariak barne. Azterketa honetan, parte-hartzaileei ataza zehatzak esleitu ordez, arbelaren erabilera arrunta egiteko eskatu zitzaien: arriskuan zeuden pazienteen identifikazioa eta preskripzio-jardunbide egokien sustapena. Azterketa honek Erresuma Batuko Osasun Zerbitzu Nazionaleko Ikerketarako Etika Zerbitzu Nazionalaren onespen etikoa jaso zuen (15/NW/0792 erreferentzia-zenbakia).

\section{ERAUZITAKO EZAUGARRIAK}

Atal honetan, bi erabiltzaile-azterketetako parte-hartzaileen begirada eta elkarrekintza neurtzeko definitutako metrikak azalduko ditugu.

\subsection{Begiradaren ezaugarriak}

Laborategiko azterketari dagokion begiradaren $(B)$ ezaugarri gisa, bederatzi interes-eremuetako bakoitzean (IE1-IE9) begi-arakatzaileak bildutako batez besteko begiradaren finkapenaren iraupena $(f)$ erabili genuen, segundotan (s) neurtua, 1. ekuazioan erakusten den bezala,

$$
B=\left(f_{I E 1}, \ldots, f_{I E 9}\right)
$$

Jakin badakigu begiradaren finkapenaren iraupena karga kognitiboaren proxy edo adierazle bat dela [11]. Gure premisa da, beraz, SMASH arbeleko portaera bisuala eta interaktiboa erlazionatzeko garaian karga kognitiboa adierazle egokia izan daitekeela parte-hartzaileak profilatzeko.

\subsection{Elkarrekintzaren ezaugarriak}

SMASHek bildutako log fitxategien informazioan oinarrituta (erabiltzailearen eta saioaren identifikatzaileak, gertaerak, denbora-markak eta URLak) bi azterketetarako (laborategikoa eta behaketakoa) kalkulatu genituen ezaugarriak esplorazioaren eta permanentziaren denbora-tarteak izan ziren. Bi ezaugarriak kalkulatzeko, klik-gertaerak erreferentzia gisa erabiltzen dira, jakinda klik batek uneko pantailaren ikuspegia eguneratzen duela informazioa iragaziz, edo arbelaren beste pantaila batera bideratzen gaituela.

- Esplorazioa (e):

Saguaren ondoz ondoko bi kliken arteko sagu-pausatze kopuruaren mediana gisa definitu genuen. Metrika hau esplorazio bisuala kuantifikatzeko erabil daiteke, saguaren kokapena pantailan begiradaren 
kokapenaren proxy bat baita [12]. Esplorazio-balio altuek bilaketa bisualen jarduera gehiago iradokitzen dituzte.

- Permanentziaren denbora-tartea $(d)$ :

Saguaren ondoz ondoko bi kliken artean igarotako denbora-tartearen mediana gisa definitu genuen, segundotan (s) adierazia. Pantaila batean egondako denbora, izan ere, erabiltzaileek informazioa prozesatzeko eta arazoak konpontzeko duten eraginkortasunaren adierazle da. Ikerketa baten arabera, informazioa bilatzeko atazetan, denbora luzeenak gaitasun kognitibo txikiagoarekin lotzen dira [7]. Hori horrela, denbora-tarte laburragoek atazak burutzeko eraginkortasun handiagoa adierazten dute.

Ezaugarri hauek erabiliz, bi elkarrekintza-bektore sortu genituen partehartzaile bakoitzeko: batak pantaila guztietan egindako elkarrekintza biltzen du (globala $E G$ ); besteak pantaila bakoitzean egindako elkarrekintza kontuan hartzen du (pantailetan banatutakoa $E P$ ).

2. ekuazioan definitutako lehen bektoreak $(E G)$ erabiltzailearen elkarrekintza globala deskribatzen du SMASH arbelaren pantaila guztietan, eta bi ezaugarriko bektore gisa kalkulatzen da: esplorazioa (e) eta denbora-tarte $(d)$ globala.

$$
E G=(e, d)
$$

3. ekuazioan definitutako bektoreak $(E P)$ SMASH arbelaren pantaila bakoitzean $(P 1-P 7)$ erregistratutako elkarrekintza neurtzen du, aipatutako bi ezaugarrietan oinarrituta: esplorazioa $(e)$ eta denbora-tartea $(d)$. Beraz, partaide bakoitzeko 14 ezaugarriko bektore gisa irudikatzen da.

$$
E P=\left(\left(e_{P_{1}}, d_{P_{1}}\right), \ldots,\left(e_{P_{7}}, d_{P_{7}}\right)\right)
$$

\section{DATU-BASEEN DESKRIBAPENA}

Atal honetan, bi azterketetan erauzitako bektoreekin eraikitako hiru datu-base deskribatuko ditugu: batek laborategiko azterketako begirada-datuak erabiltzen ditu, eta beste biek laborategiko nahiz behaketa-azterketetako elkarrekintza-datuak.

\subsection{Begiradaren datu-basea: laborategiko azterketa}

1. taulak laborategiko azterketako partaideentzat (P1-P6) begiradaren bektorearekin (ikus 1. ekuazioa) sortutako datu-basea erakusten du. Taulan ageri den moduan, interes-eremu bakoitzean erregistratutako batez besteko begiradaren finkapenaren iraupena, $\left(f_{I E 1}, \ldots, f_{I E 9}\right)$, jasotzen du segundotan. 
1. taula. Begiradaren bektorearen (Bek. zutabea) balioak laborategiko parte-hartzaileentzat (Par. zutabea).

\begin{tabular}{ccrcccccccc}
\hline \multicolumn{10}{c}{ Begiradaren finkapenaren iraupena interes-eremu bakoitzean } \\
\hline Par. & Bek. & \multicolumn{1}{c}{$f_{I E 1}$} & \multicolumn{1}{c}{$f_{I E 2}$} & $f_{I E 3}$ & $f_{I E 4}$ & $f_{I E 5}$ & $f_{I E 6}$ & $f_{I E 7}$ & $f_{I E 8}$ & $f_{I E 9}$ \\
\hline P1 & B & 0,0 & 173,3 & 241,9 & 167,0 & 254,5 & 240,1 & 168,1 & 164,3 & 140,6 \\
P2 & B & 230,2 & 223,0 & 213,2 & 158,5 & 200,8 & 222,9 & 228,0 & 207,2 & 148,5 \\
P3 & B & 212,9 & 220,5 & 268,7 & 295,0 & 294,0 & 248,2 & 244,7 & 263,2 & 235,5 \\
P4 & B & 223,2 & 250,0 & 299,3 & 289,4 & 260,4 & 234,5 & 275,4 & 203,1 & 79,0 \\
P5 & B & 201,6 & 151,4 & 201,2 & 189,0 & 264,8 & 163,0 & 243,3 & 278,9 & 91,5 \\
P6 & B & 193,5 & 173,4 & 248,8 & 0,0 & 254,9 & 204,2 & 151,2 & 176,1 & 157,5 \\
\hline
\end{tabular}

\subsection{Elkarrekintza datu-baseak: behaketa-azterketa eta laborategikoa}

2. taulak bi elkarrekintzetarako (globala eta pantailetan banatutakoa) 2 . eta 3. ekuazioetan adierazitako ezaugarriek dituzten balioak erakusten ditu bi datu-baseetarako.

Lehenengo datu-baserako, laborategiko azterketako datuak erabili genituen; bigarrenerako, aldiz, datu horiei behaketa-azterketako datubasean bildutakoak batu genizkien: sei eta 41 subjektu, hurrenez hurren. Behaketa-azterketaren kasuan, zehazki, $E G$ eta $E P$ ezaugarriak kalkulatzeko parte-hartzaile bakoitzak arbelarekin egindako elkarrekintza guztia erabili genuen; hots, subjektu bakoitzaren saio guztiak bateratu genituen.

Taulan bi bektore horien oinarri diren ezaugarriak (taulan Ez.) daude ikusgai: esplorazioa, $e /\left(e_{P_{1}}, \ldots, e_{P_{7}}\right)$, eta permanentziaren denbora-tartea, $d /\left(d_{P_{1}}, \ldots, d_{P_{7}}\right)$. Behaketa-azterketaren kasuan, 35 parte-hartzaileen (taulan PB errenkadak) ezaugarrien batezbestekoa erakusten da. 
Ainhoa Yera, Olatz Arbelaitz, Javier Muguerza, Iñigo Perona, Markel Vigo

2. taula. Bi elkarrekintza-bektoreen (Bek. zutabea) balioak (globala eta pantailetan banatutakoa) (EG/EP), laborategiko azterketako nahiz behaketa-azterketako (P1-P6/PB) parte-hartzaileentzat.

\begin{tabular}{|c|c|c|c|c|c|c|c|c|c|c|}
\hline \multirow{2}{*}{ Par. } & \multirow{2}{*}{ Bek. } & \multirow{2}{*}{ Ez. } & \multirow{2}{*}{ Globala } & \multicolumn{7}{|c|}{ Pantailak $(P j)$} \\
\hline & & & & $P 1$ & $P 2$ & $P 3$ & $P 4$ & $P 5$ & $P 6$ & $P 7$ \\
\hline & & $e$ & 4,00 & & & & & & & \\
\hline & EG & $d$ & 4,28 & & & & & & & \\
\hline & & $e_{P j}$ & & 3,00 & 4,00 & 3,00 & 6,00 & 0,00 & 4,00 & 0,00 \\
\hline \multirow[t]{4}{*}{$\mathrm{P} 1$} & EP & $d_{P j}$ & & 3,90 & 6,50 & 3,75 & 6,95 & 0,00 & 2,80 & 0,00 \\
\hline & & $e$ & 5,00 & & & & & & & \\
\hline & EG & $d$ & 6,54 & & & & & & & \\
\hline & & $e_{P j}$ & & 5,50 & 5,00 & 3,00 & 4,00 & 0,00 & 3,00 & 0,00 \\
\hline \multirow[t]{4}{*}{$\mathrm{P} 2$} & EP & $d_{P j}$ & & 6,03 & 9,23 & 2,99 & 3,35 & 0,00 & 1,22 & 0,00 \\
\hline & & $e$ & 4,00 & & & & & & & \\
\hline & EG & $d$ & 3,22 & & & & & & & \\
\hline & & $e_{P j}$ & & 3,50 & 4,00 & 3,00 & 3,50 & 0,00 & 3,00 & 4,00 \\
\hline \multirow[t]{4}{*}{ P3 } & $\mathrm{EP}$ & $d_{P j}$ & & 2,37 & 4,49 & 4,88 & 3,01 & 0,00 & 4,22 & 2,41 \\
\hline & & $e$ & 3,00 & & & & & & & \\
\hline & EG & $d$ & 3,31 & & & & & & & \\
\hline & & $e_{P j}$ & & 4,00 & 3,00 & 3,50 & 2,00 & 0,00 & 2,00 & 0,00 \\
\hline \multirow[t]{4}{*}{$\mathrm{P} 4$} & EP & $d_{P j}$ & & 5,36 & 3,82 & 4,11 & 0,95 & 0,00 & 0,64 & 0,00 \\
\hline & & $e$ & 3,00 & & & & & & & \\
\hline & EG & $d$ & 2,26 & & & & & & & \\
\hline & & $e_{P j}$ & & 3,00 & 3,00 & 3,00 & 3,00 & 5,00 & 3,00 & 0,00 \\
\hline \multirow[t]{4}{*}{ P5 } & $\mathrm{EP}$ & $d_{P j}$ & & 2,77 & 1,71 & 1,90 & 2,18 & 3,60 & 5,76 & 0,00 \\
\hline & & $e$ & 4,00 & & & & & & & \\
\hline & EG & $d$ & 9,43 & & & & & & & \\
\hline & & $e_{P j}$ & & 9,00 & 4,00 & 3,00 & 6,00 & 4,00 & 0,00 & 0,00 \\
\hline \multirow[t]{4}{*}{ P6 } & EP & $d_{P j}$ & & 36,39 & 6,20 & 6,59 & 7,13 & 5,40 & 0,00 & 0,00 \\
\hline & & $e$ & 3,40 & & & & & & & \\
\hline & EG & $d$ & 3,47 & & & & & & & \\
\hline & & $e_{P j}$ & & 3,84 & 3,21 & 3,29 & 2,83 & 2,34 & 1,87 & 1,60 \\
\hline $\mathrm{PB}$ & $\mathrm{EP}$ & $d_{P j}$ & & 8,93 & 2,75 & 16,02 & 3,68 & 6,28 & 2,15 & 7,93 \\
\hline
\end{tabular}




\section{EMAITZAK ETA ANALISIA}

\subsection{Laborategiko begirada-datuen azterketa}

Interes-eremu desberdinetan begiradaren finkapenaren antzeko iraupenak dituzten parte-hartzaileak, $\left(f_{I E 1}, \ldots, f_{I E 9}\right)$, aurkitzeko, Pearsonen korrelazio-analisia egin genuen $B$ bektoreen artean. Analisi horretan, bi parte-hartzaileren arteko korrelazio positiboak antzeko portaera bisuala adieraziko luke karga kognitiboari dagokionez. Zehazki, antzeko portaera bisuala zuten parte-hartzaileak parekatzeko, kasu bakoitzean eskuratutako korrelazio-baliorik altuena erabili genuen. 3. taulak Pearsonen korrelazio-koefizientearen ( $r$ ) emaitzak erakusten ditu; parte-hartzaileak bikoteka elkar daitezkeela ikus daiteke: P1-P3 $(r=0,63), \mathrm{P} 2-\mathrm{P} 6(r=0,55)$ eta P4-P5 $(r=0,53)$.

3. taula. Pearsonen korrelazio-koefizientea (r) laborategiko sei parte-hartzaileen (P1-P6) begirada-datuetarako kalkulatua. Partaide bakoitzarentzat baliorik altuena letra lodiz eta kolorez adierazita dago.

\begin{tabular}{|c|c|c|c|c|c|c|}
\hline & P1 & P2 & P3 & P4 & P5 & P6 \\
\hline P1 & 1,00 & $-0,05$ & $\mathbf{0 , 6 3}$ & 0,33 & 0,15 & 0,26 \\
\hline P2 & 0,05 & 1,00 & $-0,40$ & 0,47 & 0,42 & $\mathbf{0 , 5 5}$ \\
\hline P3 & $\mathbf{0 , 6 3}$ & $-0,40$ & 1,00 & 0,41 & 0,45 & $-0,18$ \\
\hline P4 & 0,33 & 0,47 & 0,41 & 1,00 & $\mathbf{0 , 5 3}$ & $-0,03$ \\
\hline P5 & 0,15 & 0,42 & 0,45 & $\mathbf{0 , 5 3}$ & 1,00 & 0,20 \\
\hline P6 & 0,26 & $\mathbf{0 , 5 5}$ & $-0,18$ & $-0,03$ & 0,20 & 1,00 \\
\hline
\end{tabular}

\subsection{Laborategiko elkarrekintza-datuen azterketa}

Antzeko portaera interaktiboak erakutsi zituzten laborategiko azterketako erabiltzaileak identifikatze aldera, k-means eta single-linkage [14] clustering algoritmoak aplikatu genizkien definitutako bi elkarrekintzabektoreei.

Zehazki, k-means algoritmoak ( $\mathrm{k}=3$ eta distantzia euklidearra) klinikoak bina elementuko hiru klusterretan taldekatu zituen $E G$ metrikarentzat: P4-P5, P1-P3 eta P2-P6. Silhouette kluster baliozkotasun-indizearekin (CVI) [2] egindako analisiak adierazi zuen elkarrekintza globalarentzat kluster-konfiguraziorik egokiena $\mathrm{k}=3$ zela, $\mathrm{k}=4$ eta $\mathrm{k}=5$ konfigurazioekin alderatuta, hurrenez hurren 0,51,0,20 eta 0,003 emaitzak lortu baitziren. Ondoriozta daitekeenez, Silhouette indizearen balioa zenbat eta handiagoa izan, partizioa are eta hobeagoa da. 
Ainhoa Yera, Olatz Arbelaitz, Javier Muguerza, Iñigo Perona, Markel Vigo

Metodo bera aplikatu genuen pantailetan banatutako elkarrekintza-bektoreetan, hau da, k-means algoritmoa egikaritu genuen distantzia euklidearra erabiliz. Era berean, k-ren balioa hautatzeko Silhouette erabili genuen, zeinak adierazi zuen erabilitako balioen artean $(\mathrm{k} \in\{3,4,5\})$, nahiz eta balioak txikiak izan, egokiena $\mathrm{k}=3$ zela; hurrenez hurren, emaitza hauekin: $0,002,-0,011$ eta $-0,046$.

Erabiltzaileen elkarrekintza-datuetan aurkitutako patroiek eta agertutako begirada-patroiek talde berberak sortzen dituzte. Beraz, ondorioztatu da erlazionatutako portaera bisuala dutela antzeko portaera interaktiboa duten banakoek. Zehazki, antzeko karga kognitiboa duten pertsonek (begi-radaren finkapenaren iraupenek adierazten duten bezala) sagua elkarren antzera erabiltzen dutela erakusten dute, SMASH arbelean globalki nahiz haren zazpi pantailetan, esplorazioen eta denbora-tarteen ezaugarriek adierazi moduan.

Parte-hartzaileen taldekatzeak sakonago aztertze aldera, bi elkarrekintza-bektoreei ( $E G$ eta $E P$ ) aplikatutako clustering prozeduretan lortutako subjektu-bikoteen hurbiltasun-analisia egin genuen, distantzia-matrizeak ( $\mathrm{d}$ = euklidearra) aztertuz. Analisitik, P2-P6 bikotea besteak baino urrunago zegoela ondorioztatu genuen: alegia, kluster hori ez zela besteak bezain trinkoa. Elkarrekintza globalaren kasuan, P1-P3, P2-P6 eta P4-P5 bikoteen arteko distantzia euklidearraren balioak 1,06, 3,06 eta 1,05 izan ziren hurrenez hurren; pantailetan banatutako elkarrekintzaren kasuan, aldiz, 7,38, 32,11 eta 9.21. Bi kasuetan egiaztatu genuen P6 parte-hartzailea zela, oro har, besteengandik urrutien zegoen subjektua.

\subsection{Behaketa-azterketako elkarrekintza-datuen analisia}

Azkenik, aurreko clustering prozedurari jarraituz, erabiltzaile guztien elkarrekintza-datuak batera aztertu genituen, hots, laborategiko eta behaketaazterketetako datu-baseak bateratuz. Helburua zen laborategiko parte-hartzaileak kluster berri hauetan nola taldekatzen ziren aztertzea eta aurreko clustering prozedurarekin eratutako bikoteak mantentzen ote ziren egiaztatzea. Erabiltzaile-bikoteak berriz ere modu berean elkartuz gero, pentsa genezake haiekin kluster berean bildutako behaketa-azterketako parte-hartzaileek laborategiko homologoen antzeko portaera bisuala izango dutela.

Beraz, analisia errepikatu genuen k-means algoritmoa (distantzia euklidearra) estandarizatutako elkarrekintza globalaren bektoreei aplikatuz; analisi honetan, 41 parte-hartzaile erabili genituen (hau da, behaketa-azterketako 35 parte-hartzaile + laborategiko sei). Silhouette klusterraren baliozkotasun-indizearekin (CVI) egindako analisiak adierazi zuen, berriz ere, $\mathrm{k}=3$ zela konfiguraziorik egokiena aztertutako $\mathrm{k}$ guztientzat $(3 \leq \mathrm{k} \leq 10)$. 4. taulak eta 4. irudiak erakusten dute nola banatzen diren laborategiko azterketako parte-hartzaileak sortutako klusterretan. 
4. taula. k-means-en emaitzak $(\mathrm{k}=3, \mathrm{~d}=$ euklidearra), normalizatutako elkarrekintza globalerako, laborategiko eta behaketa-azterketako parte-hartzaileak bateratzean.

\begin{tabular}{lccc}
\hline & 1. klusterra & 2. klusterra & 3. klusterra \\
\hline Laborategiko parte-hartzaileak & P6 & P1, P2, P3 & P4, P5 \\
Behaketa-azterketako parte-hartzaile kopurua & 2 & 19 & 14 \\
\hline
\end{tabular}

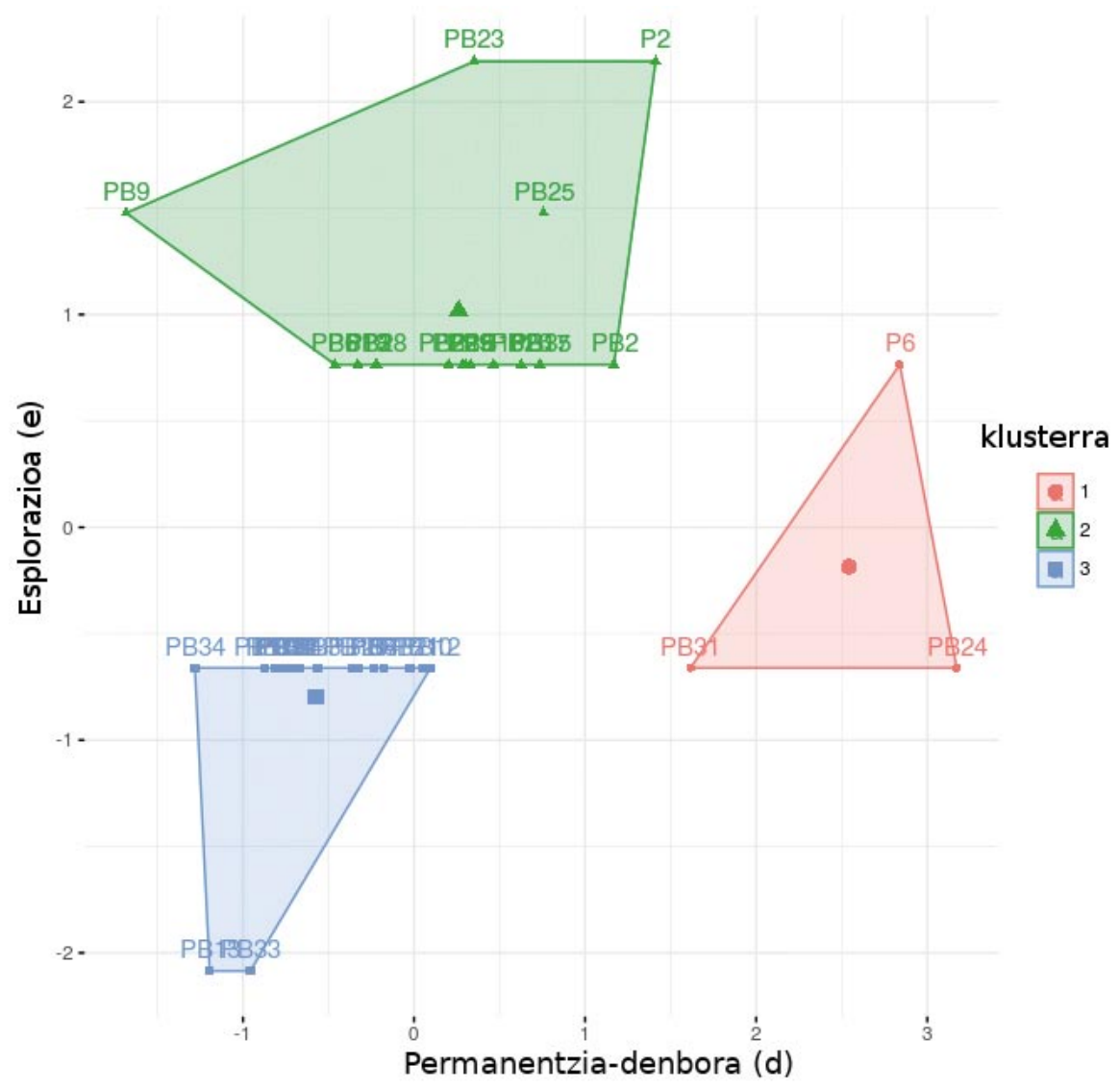

4. irudia. k-means-en $(\mathrm{k}=3, \mathrm{~d}=$ euklidearra) irudikapen grafikoa, normalizatutako elkarrekintza globalerako (laborategiko eta behaketa-azterketako parte-hartzaileak).

Emaitzen arabera laborategiko sei parte-hartzaileak modu bertsuan taldekatu ziren. P2 izan zen talde desberdin batean bildutako subjektu bakarra; P6-rekin taldekatu ordez, P1-P3 bikotearen taldera mugitu zen. Aurrez 
Ainhoa Yera, Olatz Arbelaitz, Javier Muguerza, Iñigo Perona, Markel Vigo

egindako hurbiltasun-analisiaren arabera, P2 eta P6 parte-hartzaileen klusterra ezegonkorragoa izateak ulergarria egiten du P2 subjektua taldez aldatzea. Zentzu honetan, 4. irudiak erakusten du P6 subjektua parte-hartzaile gutxirekin bildu zela; permanentzia-denbora altuek baldintzatutako portaera berezia zutenekin, hain zuzen (1. klusterra). Modu berean, P2 (esploraziorik altuena duen subjektua) 2. klusterreko mugan kokatuta zen, bertan bildutako gehienek baino elkarrekintza global altuagoa zuelarik. Beste bikoteak, ostera, irudian hauteman daitekeenez, trinkoagoak ziren eta portaera ohikoenak zituzten; 2. eta 3. klusterretan, P1-P3 eta P4-P5 parte-hartzaileak gertu daude elkarrengandik, eta dentsitate handiko zonaldeetan, zentroideen ondoan hain zuzen.

\section{ONDORIOAK ETA ETORKIZUNERAKO LANAK}

Ekarpen honetan, arbel mediko baten (SMASH) erabiltzaileek duten portaera bisualaren eta elkarrekintzaren artean dagoen erlazioa aztertu dugu, arbelarekin egindako bi azterlanetan (laborategikoa eta behaketakoa) bildutako datuak aztertuz.

Laborategiko azterketako elkarrekintza-datuen gainean egindako clustering-analisiak erakutsi zuen erabiltzaileen elkarrekintzaren portaera antzekoa izan zela arbelaren pantaila guztietan. Portaera hori desberdina izan zen kasuetan, pantaila espezifiko bateko portaera ezberdina zenean, hau modu bertsuan aldatu zen kluster barruko parte-hartzaileen artean. Aurkikuntza horrek iradokitzen du pantaila espezifikoa erabiltzaile-ereduan txertatzeak agian ez duela inolako eraginik denbora-tarte eta esploraziometriken gainean (ondoz ondoko bi kliken arteko denbora-tartea eta sagupausatzea, hurrenez hurren).

Bestetik, laborategiko azterketan jasotako begiradaren datuekin egindako korrelazio-analisian aurkitutako parte-hartzaile taldeak bat datoz elkarrekintzaren datuen clustering-ean lortutakoekin. Horrek esan nahi du portaera interaktibo berezia erakutsi zuten parte-hartzaileek antzeko portaera bisuala izan zutela. Begirada arretaren proxy bat denez eta, aldi berean, arreta ekintzaren aurretik dagoenez [13], esan dezakegu taldekatze horiek ez direla ausazkoak izan. Beraz, portaera interaktibo zehatzak erakustea neurri batean interes-eremu espezifikoetako begiradaren finkapenaren iraupenaren araberakoa izan daitekeela esan genezake.

Azkenik, SMASH arbela eguneroko jarduera gisa erabili zuten behaketa-azterketako parte-hartzaileen elkarrekintza-datuen analisiak erakutsi zuen ezen, atazak desberdinak izan arren, portaerak egonkorrak izan zirela bi inguruneetan. Behaketa-azterketako parte-hartzaileen begiradari buruzko daturik izan gabe, pentsa genezake haien portaera bisuala haiekin taldekatutako laborategiko parte-hartzaileek izan zutenaren antzekoa 
izan zela. Etorkizuneko lanak, zalantzarik gabe, aurkikuntza honetan sakonduko du.

Lanaren ondorioek etorkizun handia dute, portaera bisuala elkarrekintza-datuak soilik erabiliz inferitzeko aukera ematen baitute. Elkarrekintza-datuen analisi batzuk denbora errealean egin daitezke nabigatzailean. Elkarrekintza-datuak prozesatzea eta aztertzea erraza da, betiere ezaugarri zuzenak erauzten badira, baina epe ertainean ez da espero begi-arakatzailea laborategiko ingurunetik kanpo erabiltzea. Elkarrekintza eta begiradaren jarduera neurtzeko erabilitako ezaugarriak honako helburuetarako erabil daitezke: 1) denbora errealeko erabilgarritasun-arazoak ondorioztatzeko eta 2) erabiltzaile-interfazean egokitzapenak jakinarazteko. Egokitzapen horiek datuen ikuspegi gisa ezar litezke arbel medikoen informazio-gainkarga murrizteko. Hori datuen taulen zuzeneko maneiua ahalbidetuz [26] eta bistaratze iragankorrak erabiliz [21] erdiets liteke.

\section{ESKERRAK}

Lan honek honako iturrien finantzaketa jaso du: NIHR Greater Manchester PSTRC eta MRC Health eResearch Centre, UK (MR/ K0065/1), Euskal Herriko Unibertsitatea (PIF15/143 beka), Eusko Jaurlaritzako Hezkuntza Saileko Unibertsitateak eta Ikerketa Atalak sustengatzen duen ADIAN ikerketa taldea (IT980-16 erreferentzia), eta, azkenik, Espainiako Gobernuko Ekonomia eta Lehiakortasun Ministerioa, ERDFak lagunduta (Physcomp, TIN2017-85409-P).

\section{BIBLIOGRAFIA}

[1] AKBAROV, A., KONTOPANTELIS, E., SPERRIN, M., STOCKS, S.J., WILLIAMS, R., RODGERS, S., AVERY, A., BUCHAN, I. eta ASHCROFT, D.M. 2015. «Primary care medication safety surveillance with integrated primary and secondary care electronic health records: a cross-sectional study». Drug Saf, (38)7, 671-682.

[2] ARBELAITZ, O., GURRUTXAGA, I., MUGUERZA, J., PÉREZ, J, eta PERONA, I. 2013. «An extensive comparative study of cluster validity indices». Pattern Recognition, (46)1, 243-256.

[3] AVERY, A., RODGERS, S., CANTRILl, J.A., ARMSTRONG, S., CRESSWELL, K., EDEN, M., ELLIOT, R.A., HOWARD, R., KENDRICK, D., MORRIS, C.J., PRESCOTT, R.J, SWANWICK, G., FRANKLIN, M., PUTMAN, K., BOYD, M. eta SHEIKH, A. 2012. «A pharmacistled information technology intervention for medication errors (pincer).: a multicentre, cluster randomised, controlled trial and cost-effectiveness analysis». The Lancet, (379)9823, 1310-1319. 
Ainhoa Yera, Olatz Arbelaitz, Javier Muguerza, Iñigo Perona, Markel Vigo

[4] BREHAUT, J., COLQUHOUN, H., EVA, K., CARROLL, K., SALES, A., MICHIE, S., IVERS, N. eta GRIMSHAW, J. 2016. «Practice feedback interventions: 15 suggestions for optimizing effectiveness». Ann Inter Med, (164)6, 435-441.

[5] BROWN, B., BALATSOUKAS, P., WILLIAMS, R., SPERRIN, M. eta BUCHAN, I. 2016 «Interface design recommendations for computerised clinical audit and feedback: Hybrid usability evidence from a research-led system». Int J Med Inform, 94, 191-206.

[6] CHEN, M., ANDERSON, J. eta SOHN, M. 2001. «What can a mouse cursor tell us more?: Correlation of eye/mouse movements on web browsing». CHI '01 Extended Abstracts on Human Factors in Computing Systems (CHI EA '01), 281-282.

[7] CHIN, J., FU, W. eta KANNAMPALLIL, T. 2009. «Adaptive information search: Agedependent interactions between cognitive profiles and strategies». 27th ACM Conference on Human Factors in Computing Systems (CHI '09)-ko aktetan, 1683-1692.

[8] DAGliATI, A., SACCHI, L., TIBOLlO, V., COGNI, G., TEliTi, M., MARTINEZ-MILLANA, A., TRAVER, V., SEGAGNI, D., POSADA, J., OTTAVIANO, M., FICO, G., ARREDONDO, M., DE CATA, P., CHIOVATO, L. eta BELLAZZI, R. 2018. «A dashboard- based system for supporting diabetes care». J Am Med Inform Assoc, (25)5, 538-547.

[9] DOWDING, D., MERRILL, J., ONORATO, N., BARRÓN, Y., ROSATI, R. eta RUSSELL, D. 2017. «The impact of home care nurses' numeracy and graph literacy on comprehension of visual display information: Implications for dashboard design». J Am Med Inform Assoc, (25)2, 175-182.

[10] DOWDING, D., RANDELL, R., GARDNER, P., FITZPATRICK, G., DYKES, P., FAVELA, J., HAMER, S., WHITEWOOD-MOORES, Z., HARDIKER, N., BORYCKI, E. eta CURRIE, L. 2015. «Dashboards for improving patient care: Review of the literature». Int J Med Inform, (84)2, 87100.

[11] EHMKE, C. eta WILSON, S. «Identifying web usability problems from eyetracking data». 2007. 21st British HCI Group Annual Conference on People and Computers: HCI...But Not As We Know It - Volume 1 (BCS-HCI '07)-ko aktetan, 119-128.

[12] GUO, Q. eta AGICHTEIN, E. 2010. «Towards predicting web searcher gaze position from mouse movements». CHI'10 Extended Abstracts on Human Factors in Computing Systems (CHI EA '10), 3601-3606.

[13] HUANG, J., WHITE, R. eta BUSCHER, G. 2012. «User see, user point: Gaze and cursor alignment in web search». SIGCHI Conference on Human Factors in Computing Systems (CHI'12)-ko aktetan, 1341-1350.

[14] JAIN, A. eta DUBES, R. 1988. «Algorithms for Clustering Data», PrenticeHall, Inc., New Jersey.

[15] JEFFRIES, M., KEERS, R., PHIPPS, D., WILLIAMS, R., BROWN, B., AVERY, A., PEEK, N. eta ASHCROFT, D. 2018. «Developing a learning 
health system: Insights from a qualitative process evaluation of a pharmacist-led electronic audit and feedback intervention to improve medication safety in primary care». PLOS ONE, (13)10, 1-16.

[16] KALRA, D., BUCHAN, I. eta PATON, N. 2016. «Three gurus of big data. [Internet]». The Translational Scientist, 816, 401. [Eguneratua: 201611-23; Kontsulta: 2020-04-24]. Eskuragarri: https://thetranslationalscientist. com/tools-techniques/three-gurus-of-big-data

[17] KEERS, R., WILLIAMS, R., DAVIES, C., PEEK, N. eta ASHCROFT, D. 2018. «Improving medication safety in primary care: developing a stakeholder-centred electronic prescribing safety indicator dashboard»., Prescribing and Research in Medicines Management (PRIMM) 26th Annual Scientific Meeting, (27)7, O26-O27.

[18] KUSHNIRUK, A. eta PATEL, V. 2004. «Cognitive and usability engineering methods for the evaluation of clinical information systems».J Biomed Inform, (37)1, 56-76.

[19] LANDIS-LEWIS, Z., C BREHAUT, J., HOCHHEISER, H., DOUGLAS, G. eta S JACOBSON, R. 2015. «Computer-supported feedback message tailoring: Theory-informed adaptation of clinical audit and feedback for learning and behavior change». Implement Sci, (10) 1,12 .

[20] Middleton, B., BloOmRosen, M., DENTE, M., HAShMAT, B., KOPPEL, R., OVERHAGE, J., PAYNE, T., ROSENBLOOM, S., WEAVER, C. eta ZHANG, J. 2013. «Enhancing patient safety and quality of care by improving the usability of electronic health record systems: recommendations from amia». J Am Med Inform Assoc, (20)e1, e2-e8.

[21] PERIN, C., VUILLEMOT, R. eta FEKETE, J. 2014. «A table!: Improving temporal navigation in soccer ranking tables». 32nd Annual ACM Conference on Human Factors in Computing Systems (CHI'14)-ko aktetan, 887-896.

[22] RATWANI, R., FAIRBANKS, R., HETTINGER, A. eta BENDA, N. 2015. «Electronic health record usability: analysis of the user-centered design processes of eleven electronic health record vendors». J Am Med Inform Assoc, (22)6, 1179-1182.

[23] SIMPAO, A.F., AHUMADA, L.M., DESAI, B.R., BONAFIDE, C.P., GÁLVEZ, J.A., REHMAN, M.A., JAWAD, A.F., PALMA, K.L. eta SHELOV, E.D. 2014. «Optimization of drug-drug interaction alert rules in a pediatric hospital's electronic health record system using a visual analytics dashboard». J Am Med Inform Assoc, (22)2, 361-369.

[24] STOCKS, S., KONTOPANTELIS, E., AKBAROV, A., RODGERS, S., AVERY, A. eta ASHCROFT, D. 2015. «Examining variations in prescribing safety in uk general practice: cross sectional study using the clinical practice research datalink». BMJ, (351)h5501.

[25] TOBII TECHNOLOGY AB 2014. «Tobii X2-60 Eye Tracker User Manual [Internet]». [Eguneratua: 2014-06-01; Kontsulta: 2020-07-10]. Eskuragarri: https://www.tobiipro.com/siteassets/tobii-pro/user-manuals/tobii-prox2-60-eye-tracker-user-manual.pdf/?v=1.0.3 
Ainhoa Yera, Olatz Arbelaitz, Javier Muguerza, Iñigo Perona, Markel Vigo

[26] VUILLEMOT, R. eta PERIN, C. 2015. «Investigating the direct manipulation of ranking tables for time navigation». 33rd Annual ACM Conference on Human Factors in Computing Systems (CHI'15)-ko aktetan, 2703-2706.

[27] WILLIAMS, R., KEERS, R., GUDE, W., JEFFRIES, M., DAVIES, C., BROWN, B., KONTOPANTELIS, E., AVERY, J., ASHCROFT, M. eta PEEK, N. 2018. «Smash! the salford medication safety dashboard». J Innov Health Inform, (25)3, 183-193.

[28] ZAHABI, M., KABER, D. eta SWANGNETR, M. 2015. «Usability and safety in electronic medical records interface design: A review of recent literature and guideline formulation». Hum Factors, (57)5, 805-834.

[29] ZHANG, J. eta WALJI, M. 2011. «Turf: Toward a unified framework of ehr usability». Journal of Biomedical Informatics, (44)6, 1056-1067. 